\title{
UJI VALIDITAS ISI MODUL PERMAINAN EDUKATIF BERJALAN DAN BERHENTI (B\&B) UNTUK MENINGKATKAN KEMAMPUAN VISUAL SPASIAL ANAK USIA DINI
}

\section{VALIDITY TEST OF THE CONTENT FROM MODULE EDUCATIVE GAME BERJALAN DAN BERHENTI (B\&B) TO IMPROVE SPATIAL VISUAL ABILITIES FOR EARLY CHILDREN}

\author{
${ }^{1}$ Putri Mayang Sari, ${ }^{2}$ Yun Nina Ekawati, ${ }^{3}$ Dessy Pramudiani \\ ${ }^{1,2,3}$ Departement of Psychology, Jambi University / putrimayangsari77@ gmail.com
}

\begin{abstract}
Introduction Visual spatial abilities in early childhood were still need to be improved. This is shown from the results of data observations, interviews and data from the school regarding the visual spatial abilities of children in the kindergarten. Therefore it was need to be stimulated through the educational game berjalan dan berhenti $(B \& B)$.
\end{abstract}

Method This research was used a descriptive study with a $3 D$ (define, design and develop). Validation was done by assessed the validity of the content in the module and measured tools for early childhood visual spatial abilities. Descriptive analysis was used as a data analysis in this research.

Results This study shows that the results of the validation from the module content and measuring instruments assessed by the validator were the $V$ score range moves from 0.75 to 0.88 .

Conclusion And Recommendation There were a suitability about the results of the validity of the contents in the module educational games berjalan dan berhenti $(B \& B)$ to improve visualspatial abilities of early childhood based on the results with the module content validity test. The researcher hope by doing this research, the educational games berjalan dan berhenti $(B \& B)$ could be a solution to improved the visual spatial abilities for early childhood.

Keywords : Module Validity, Educational, Spatial Visual Ability

\section{ABSTRAK}

Pendahuluan Kemampuan visual spasial pada anak usia dini ditemukan masih perlu untuk ditingkatkan lagi. Hal tersebut ditunjukkan dari hasil data observasi, wawancara, serta data dari pihak sekolah mengenai kemampuan visual spasial anak di TK tersebut. Sehingga perlu di stimulasi melalui permainan edukatif berjalan dan berhenti (B\&B).

Metode Penelitian ini menggunakan studi deskriptif dengan model 3D (define, design dan develop). Validasi yang dilakukan yaitu menilai validitas isi pada modul serta alat ukur kemampuan visual spasial anak usia dini. Analisis data yang digunakan adalah analisis deskriptif. Hasil Penelitian ini menunjukkan hasil validasi isi modul dan alat ukur yang dinilai oleh validator menunjukkan rentang skor $\mathrm{V}$ bergerak dari $0,75-0,88$.

Kesimpulan dan Saran Adanya kesesuaian hasil skor uji validitas isi modul Permainan Edukatif Berjalan Dan Berhenti (B\&B) terhadap kemampuan visual-spasial anak usia dini berdasarkan hasil uji validitas isi modul. Permainan edukatif berjalan dan berhenti (B\&B) diharapkan dapat menjadi solusi untuk meningkatkan kemampuan visual spasial anak usia dini.

Kata Kunci: Validitas Modul, Permainan Edukatif, Kemampuan Visual Spasial 


\section{Pendahuluan}

Pendidikan anak usia dini atau yang disingkat PAUD mempunyai peran yang sangat berharga dalam perkembangan anak berikutnya. PAUD adalah pondasi dasar dalam mengembangkan berbagai potensi yang dimiliki anak. Undang-undang Republik Indonesia Nomor 20 Tahun 2003 tentang Sistem Pendidikan Nasional Bab 1 pasal 1 ayat 10, disebutkan bahwa PAUD merupakan bentuk penyelenggaraan pendidikan yang telah diterapkan sejak anak lahir sampai dengan usia anak 6 tahun. PAUD diterapkan dengan memberikan stimulasi pendidikan guna membantu anak dalam masa pertumbuhannya, perkembangan jasmani dan rohaninya supaya mempunyai kesiapan ketika anak memasuki jenjang pendidikan selanjutnya.

Menteri Pendidikan dan Kebudayaan Republik Indonesia, Nadiem Makarim menyebutkan pihak sekolah serta orang tua harus mengetahui konsep bermain dan belajar pada anak usia dini, supaya tidak terlalu terpaku pada metode belajar yang hanya pemberian materi secara langsung pada anak dan juga tidak hanya berfokus pada tercapainya kemampuan membaca, menulis dan berhitung pada anak usia dini (Kemendikbud, 2019).

Kemampuan yang perlu

dikembangkan anak tidak hanya membaca, menulis dan berhitung, tetapi masih ada kemampuan lainnya. Anak memiliki kemampuan belajar yang berbeda dengan orang dewasa. Memaksakan anak mengerjakan sesuatu yang sebenarnya anak belum siap dapat memberikan pengalaman yang tidak menyenangkan, bahkan dapat muncul penolakan.

Metode pembelajaran pada anak usia dini lebih berfokus kepada pengembangan kemampuan dengan cara bermain. Anak ketika bermain bisa menggabungkan semua kemampuan, serta dapat membangun pengetahuannya sendiri dengan mengerjakan suatu aktivitas terhadap obyek-obyek nyata. Itulah yang menjadi alasan bahwa pendidikan terhadap anak tidak dianjurkan pemberian materi secara langsung, tetapi dilakukan melalui pendekatan bermain, yang membuat pembelajaran tersebut menyenangkan bagi anak (Marlisa, 2016).

Bermain merupakan aktivitas yang dilakukan menggunakan alat maupun tanpa adanya alat yang dapat memberikan informasi, menstimulasi imajinasi, dan menimbulkan kesenangan saat anak sedang melakukannya. Fungsi permainan salah satunya dapat membantu anak dalam perkembangan kognitif (Desmita, 2015). Pendidikan anak usia dini juga harus memahami makna bermain untuk perkembangan anak, dan mendalami kecerdasan majemuk pada setiap anak agar dapat menghasilkan anak yang berkualitas. Anak yang berkualitas yaitu anak yang tumbuh dan berkembang sesuai tahap perkembangannya (Susanto, 2017: 23).

Kecerdasan majemuk atau multiple intelligence merupakan sebuah potensi dalam diri seseorang yang membutuhkan suatu rangsangan atau stimulasi dalam pengembangannya. Kecerdasan majemuk ada 9 yaitu kecerdasan visual-spasial, kecerdasan logis-matematika, kecerdasan visual-spasial, kecerdasan musikal, kecerdasan kinestetik, kecerdasan interpersonal, kecerdasan intrapersonal, kecerdasan naturalis dan kecerdasan eksistensial.

Dari beberapa jenis kecerdasan diatas, terdapat salah satu kecerdasan yang terkait dengan kemampuan seseorang ketika melakukan aktivitas membaca serta memaknai gambar, bentuk, garis, ruang, warna serta seni lukis. Kecerdasan ini berkaitan dengan sensitivitas seseorang terhadap warna, ukuran, luas, garis, bentuk dan hubungan-hubungan yang terdapat pada unsur dari suatu pola. Kecerdasan tersebut disebut kecerdasan visual-spasial (Elfiadi, 2017).

Kecerdasan visual- spasial adalah kemampuan anak dalam memahami, memproses, dan berpikir dalam bentuk visual. Seseorang yang mempunyai kemampuan visual spasial ini dapat 
menerjemahkan bentuk gambaran dalam pikirannya menjadi bentuk 2 atau 3 dimensi. Anak menjadi tertarik serta antusias ketika mengerjakan aktivitas yang ada kaitannya dengan bentuk, ukuran, posisi, arah dan warna (Rosidah, 2014).

Ciri-ciri kemampuan visual-spasial pada anak berusia 4-6 tahun menurut Surya (Anjani \& Nurjanah, 2014) yaitu anak dapat mengetahui 12 warna, anak mampu bermain puzzle tiga dimensi atau puzzle dua dimensi sampai 20 keping, anak bisa diperkenalkan dengan bentuk segi yang lebih rumit misalnya segi tujuh sampai segi sepuluh, anak memahami semua konsep arah (kanan-kiri, maju-mundur, dan lurusbelok) dan konsep posisi (kanan-kiri, atasbawah, depan-belakang dan di dalam- di luar), serta anak memahami konsep jumlah (banyak- sedikit) serta konsep ukuran (besar-kecil, panjang-pendek dan tinggirendah).

Peneliti melakukan observasi pada anak usia 4-6 tahun di salah satu PAUD Kota Jambi pada tanggal 09-10 Desember 2019 untuk pengambilan data awal, didapatkan hasil bahwa kemampuan visualspasial pada anak masih kurang berkembang yang peneliti sajikan dalam Grafik berikut:

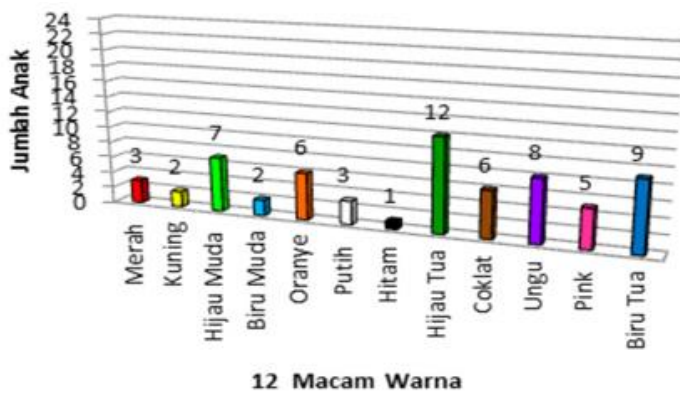

\section{Gambar 1. Data Anak Belum Mengetahui 12 Warna}

Berdasarkan hasil observasi kepada 24 anak, 4 anak bisa mengetahui dengan benar 12 jenis warna. Anak-anak masih belum mengetahui beberapa warna seperti warna merah, kuning, hijau muda, biru muda, oranye, putih, hitam, hijau tua, coklat ungu, pink dan biru tua (warna merah sebanyak 3 anak, kuning sebanyak 2 anak, hijau muda sebanyak 7 anak, biru muda sebanyak 2 anak, oranye sebanyak 6 anak, putih sebanyak 3 anak, hitam sebanyak 1 anak, hijau tua sebanyak 12 anak, coklat sebanyak 6 anak, ungu sebanyak 8 anak, pink sebanyak 5 anak dan biru tua sebanyak 9 anak)

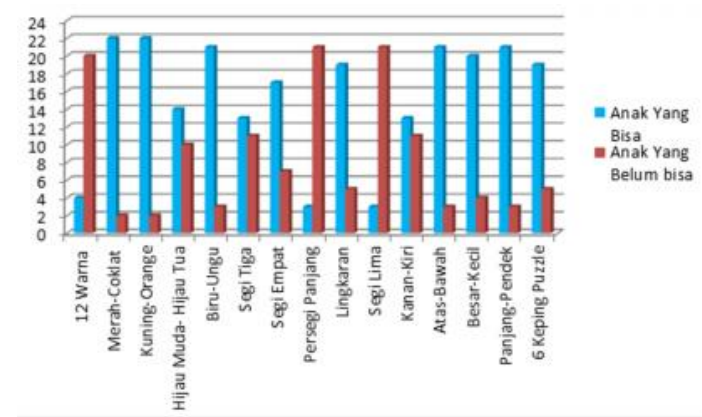

\section{Gambar 2. Hasil Observasi Kemampuan Visual Spasial Anak Usia Dini}

Anak-anak ketika disajikan 2 buah warna yang berbeda masih mengalami kesulitan. Anak masih mengalami kesulitan dalam membedakan 2 warna yang berbeda seperti warna merah dan cokelat sebanyak 2 anak, warna kuning dan oranye sebanyak 2 anak, warna hijau muda dan hijau tua sebanyak 10 anak, serta warna biru dan ungu sebanyak 3 anak. Anak-anak juga masih belum mengetahui beberapa bentuk bangun datar seperti bentuk bangun datar segitiga sebanyak 11 anak, segi emapat sebanyak 7 anak, persegi panjang sebanyak 21 anak, lingkaran sebanyak 5 anak, dan segi lima sebanyak 21 anak.

Anak-anak juga masih kesulitan dalam menentukan arah dan posisi seperti kanan dan kiri sebanyak 11 anak serta atas dan bawah sebanyak 3 anak. Anak juga kesulitan menentukan konsep ukuran seperti ukuran besar dan kecil sebanyak 4 anak serta panjang dan pendek sebanyak 3 anak. Ada 5 anak masih kesulitan dan belum mampu menyelesaikan permainan menyusun 6 keping puzzle menjadi bentuk puzzle yang utuh sesuai dengan contoh gambarnya. Mereka masih menyusun dengan posisi yang salah bahkan menyerah sebelum menyelesaikan permainan puzzle. 
Oleh karena itu, berdasarkan penjelasan di atas kemampuan visual spasial anak usia dini masih perlu untuk dikembangkan lagi.

Kemampuan visual-spasial sangat penting untuk dikembangkan pada anak usia dini. Menurut Piaget (desmita, 2015), tahap preoprational terjadi pada saat anak berusia 2-7 tahun. Tahap ini anak mulai mempresentasikan dunia dengan kata-kata dan gambar, sehingga penting untuk mengembangkan kemampuan visual spasial pada anak. Pengembangan kemampuan visual-spasial dapat membantu anak lebih kreatif dan inovatif serta bisa mengkreasikan segala sesuatu berdasarkan kemampuan sendiri.

Anak bisa menyukai permainan yang berkaitan dengan bentuk dan ruang (rancang bangun), anak bisa membaca peta serta mengingat jalan yang sudah dilewatinya, anak bisa mengukur mana yang lebih panjang dan pendek, besar dan kecil, jauh dan dekat, anak dapat memperkirakan jarak dan anak giat mengerjakan sesuatu yang ada kaitannya dengan ruang, memiliki daya problem solving atau pemecahan masalah yang baik, dan memiliki perhatian terkait hal-hal yang detail (Rosidah, 2014).

Kemampuan visual-spasial pada anak dieksplorasi, ditumbuhkan, dan dikembangkan secara optimal ketika anak menginjak dewasa. Kecerdasan yang dimiliki anak dapat diwujudkan dalam bentuk profesi dan hobi seperti melukis, menggambar, fotografi, dekorasi, membuat film dan sebagainya. Oleh karena itu, penting untuk mengembangkan kemampuan visual-spasial yang dimiliki oleh anak (Uno \& Kuadrat, 2014).

Kemampuan visual-spasial pada anak bisa dikembangkan melalui aktivitas belajar sambil bermain dengan media permainan alat permainan edukatif atau yang disingkat APE. Menurut Suryadi (Syamsuardi, 2012), salah satu dari beberapa manfaat alat permainan edukatif yaitu mengetahui warna dan bentuk. APE dapat membantu anak dalam mengetahui macam-macam bentuk (kotak/ segi empat, persegi panjang, segitiga dan lingkaran/ bulat) dan warna (kuning, merah, hijau, biru biru dan warna lainnya). Media APE juga bisa digunakan oleh anak sebagai media dalam mengembangkan kemampuan visualspasialnya.

Penelitian yang dilakukan oleh oleh Pradnyawati, dkk (2017) didapatkan hasil bahwa pembelajaran ragam hias geometri berpengaruh terhadap kecerdasan visualspasial anak kelompok B di Gugus V Kecamatan Kediri Kabupaten Tabanan tahun ajaran 2016/ 2017. Penelitian selanjutnya dilakukan oleh Rosidah (2014) didapatkan hasil bahwa Permainan maze dapat meningkatkan kecerdasan visual spasial anak TK kelompok B. Selanjutnya penelitian yang dilakukan oleh Anjani dan Nurjanah (2014) didapatkan hasil bahwa ada pengaruh permainan puzzle terhadap perkembangan kecerdasan visual-spatial anak usia 4-5 tahun di TK Al-Fath Desa Keboan Anom Gedangan Sidoarjo.

Peneliti memodifikasi permainan maze, ragam hias geometri dan puzzle menjadi suatu rangkaian permainan tersendiri. Permainan edukatif ini dinamakan permainan edukatif berjalan dan berhenti (B \& B). Permaian terdiri dari 3 sesi. Sesi pertama yaitu ragam bentuk bangun datar berjalan dan berhenti bertujuan agar anak mengetahui 12 macam warna dan mengenal bentuk bangun datar. Sesi kedua yaitu arah jejak kaki berjalan dan berhenti bertujuan agar anak mampu memahami konsep arah dan posisi serta konsep jumlah dan ukuran berjalan dan berhenti bertujuan agar anak mampu mengetahui konsep ukuran dan konsep jumlah serta dapat membedakan warna. Sesi ketiga yaitu puzzle rumah berjalan dan berhenti bertujuan agar anak mampu menyusun kepingan puzzle berdasarkan warna dan bentuk bangun datar menjadi gambar utuh berdasarkan contoh gambarnya dan dapat mengalihkan bentuk yang ditangkap mata ke wujud yang lain melalui kegiatan menggambar dan mewarnai bentuk rumah. Peserta dalam 
permainan ini yaitu anak yang berusia 4-6 tahun yang berada di kelas TK A dan TK B.

Permainan edukatif berjalan dan berhenti termasuk kedalam jenis permainan konstruktif dan permainan fungsional. Permainan konstruktif adalah suatu bentuk permainan dimana anak menggunakan suatu benda untuk menghasilkan suatu karya. Permainan ini akan mengajak anak untuk menyusun kepingan puzzle menjadi puzzle yang utuh. Anak akan menyusun kepingan puzzle berdasarkan warna, ukuran, posisi dan bentuknya. Anak juga akan diajak untuk menggambar bentuk rumah. Anak akan membentuk suatu gambar dan mewarnainya, sehingga mampu mengasah imajinasi dan kreativitas anak untuk menyelesaikannya.

Permainan ini juga termasuk permainan fungsional karena melibatkan aktifitas fisik pada anak ketika memainkannya. Anak akan berjalan sesuai dengan gambar telapak kakinya, megikuti arah tanda panah, melompati setiap bentuk bangun datar, dan berhenti ketika berada di atas tanda silang hingga sampai ke garis finis. Anak akan memainkan permainan ini diatas 3 alas permainan yang telah disiapkan sehingga sangat melibatkan aktivitas fisik atau motorik anak saat memainkannya. Adanya aktivitas fisik serta desain permainan yang menarik, anak akan menjadi lebih tertarik ketika memainkannya serta memberikan pengalaman belajar yang lebih mengesankan dan menyenangkan.

Alat permainan edukatif berjalan dan berhenti (B \& B) ini terdiri dari beragam bentuk dan warna. Ada warna merah, kuning, hijau, biru dan warna-warna lainnnya. Ada juga beberapa bentuk yaitu segi empat, segi tiga, lingkaran, persegi panjang, dan bentuk lainnya sehingga dapat menarik perhatian anak. Selain itu, terdapat berbagai arah, konsep jumlah dan ukuran sehingga permainan edukatif ini telah didesain dengan memperhatikan komponen dan ciri-ciri kemampuan visual spasial pada anak usia dini. Permainan ini telah didesain agar anak mampu mengingat apa saja yang telah diajarkan dalam permainan, anak mampu mengungkapkan kembali informasi yang telah disimpan dalam ingatan sehingga diharapkan bisa meningkatkan kemampuan visual spasial pada anak.

\section{Metode}

Metode yang digunakan dalam penelitian ini adalah studi deskriptif dengan model 3D (define, design dan develop) yaitu:

1. Tahap define dengan menganalisis kebutuhan anak usia dini khususnya kemampuan visual spasial.

2. Tahap design dengan merancang kerangka materi alat permainan edukatif berjalan dan berhenti $(B \& B)$ dalam bentuk langkah-langkah pelaksanaan permainan.

3. Tahap develop dengan melakukan validasi oleh validator yang sekaligus menjadi professional judgement (Ekawati \& Saputra, 2018).

Instrumen dalam penelitian ini menggunakan lembar validasi modul Alat permainan edukatif berjalan dan berhenti $(B \& B)$, dan skala kemampuan visualspasial anak usia dini. Menurut Azwar (2018) teknik penilaian lembar validasi modul oleh para ahli dilakukan dengan memberikan rating antara $1-5$. Penelitian ini menggunakan angka rating yang memiliki 5 kategori yaitu "Sangat tidak sesuai", "tidak sesuai", "cukup sesuai", "sesuai" dan "sangat sesuai"

Modul yang dirancang, dikonsultasikan dan diskusikan dengan pakar atau profesional yang kompeten dibidangnya. Validator bertugas menilai modul permainan yang telah dijabarkan dalam lembar validasi modul. Hasil evaluasi perbaikan oleh validator digunakan untuk merevisi modul yang telah dibuat (Ekawati \& Saputra, 2018).

Penetapan validator yang dilakukan secara purposive, yaitu berdasarkan kriteria yang telah ditentukan oleh peneliti sebagai berikut:

1. Psikolog Pendidikan, terdaftar sebagai anggota HIMPSI (Himpunan Psikologi 
Indonesia), memiliki surat izin praktik Psikolog, berpengalaman dalam memberikan psikoedukasi untuk anak usia dini, sehat jasmani dan rohani.

2. Psikolog Anak, terdaftar sebagai anggota HIMPSI (Himpunan Psikologi Indonesia), memiliki surat izin praktik Psikolog, berpengalaman dalam menangani anak usia dini, sehat jasmani dan rohani.

3. Guru. Lulusan sarjana, berpengalaman menjadi Guru TK/ PAUD minimal 2 tahun, memiliki pengalaman dalam memberikan pendidikan bagi anak usia dini, sehat jasmani dan rohani.

4. Orang tua. Lulusan D3/sarjana/magister, memiliki anak berusia 4-6 Tahun yang sedang duduk di TK/ PAUD, sehat jasmani dan rohani.

\section{Hasil}

Hasil deskriptif penelitian menggunakan studi deskriptif dengan model 3D (define, design, dan develop) sebagai berikut :

1. Tahap Pertama (define)

Pada tahap pertama, penelitian dilakukan dengan tujuan untuk melihat gambaran permasalahan di lapangan terkait dengan kemampuan visualspasial anak usia dini melalui observasi disalah satu TK di Kota Jambi kepada anak berusia 4-6 tahun yang berjumlah 24 orang anak. Observasi tersebut dilakukan pada hari Senin, 09 Desember 2019 pukul 09.30-10.30 WIB, serta hari Selasa 10 Desember 2019 pukul 08.3009.30 WIB.

Berdasarkan hasil observasi kepada 24 anak terdapat 4 anak yang bisa mengetahui dengan benar 12 jenis warna seperti warna merah, kuning, hijau muda, biru muda, oranye, putih, hitam, hijau tua, coklat ungu, pink dan biru tua. Anak kesulitan dalam membedakan 2 warna yang berbeda seperti warna merah dan coklat sebanyak 2 anak, warna kuning dan oranye sebanyak 2 anak, warna hijau muda dan hijau tua sebanyak 10 anak, serta warna biru dan ungu sebanyak 3 anak. Anak-anak juga masih belum mengetahui bangun datar segitiga sebanyak 11 anak, segi emapat sebanyak 7 anak, persegi panjang sebanyak 21 anak, lingkaran sebanyak 5 anak, dan segi lima sebanyak 21 anak.

Anak-anak juga masih kesulitan dalam menentukan kanan dan kiri sebanyak 11 anak serta atas dan bawah sebanyak 3 anak. Anak juga kesulitan menentukan konsep ukuran seperti ukuran besar dan kecil sebanyak 4 anak serta panjang dan pendek sebanyak 3 anak. Ada 5 anak masih kesulitan dan belum mampu menyelesaikan permainan menyusun 6 keping puzzle menjadi bentuk puzzle yang utuh sesuai dengan contoh gambarnya.

Peneliti juga melakukan wawancara kepada salah satu guru pada hari selasa, 10 desember 2020 guna memperdalam informasi gambaran permasalahan serta meminta data dari pihak sekolah mengenai kemampuan visual-spasial anak di TK tersebut.

Hasil data yang diperoleh dari pihak sekolah dari 30 anak, 12 anak belum mampu menggambar dan mewarnai sesuai dengan bentuk dan warnanya, 1 anak belum mampu menyusun balok, 7 anak masih memerlukan bimbingan dalam mengetahui warna, 3 anak belum mampu mengelompokkan gambar atau benda berdasarkan warna dan bentuknya, 22 anak belum mengetahui beberapa bentuk seperti segi lima, segi enam dan segi tujuh, 17 anak belum mengetahui konsep arah dan posisi, 4 anak belum memahami konsep jumlah dan ukuran, 18 anak belum mampu dalam menyusun puzzle hingga 20 keping, serta 19 anak belum bisa mengalihkan bentuk nyata (3D) kedalam bentuk gambar (2D).

Media pembelajaran yang digunakan di sekolah tersebut masih kurang dalam memfasilitasi seluruh aspek perkembangan pada anak. APE 


\section{Uji Validitas Isi Modul Permainan Edukatif Berjalan dan Berhenti (B\&B) Untuk Meningkatkan Kemampuan Visual Spasial Anak Usia Dini}

yang dimiliki sekolah masih banyak yang rusak serta kurangnya aktivitas fisik yang dilakukan saat pembelajaran membuat kurang terstimulusnya aspek perkembangan pada anak. Sehingga berdasarkan data diatas, kemampuan visual-spasial pada anak masih perlu untuk dikembangkan.

Analisis yang digunakan pada penelitian ini yaitu menggunakan analisis literatur berupa jurnal penelitian sebelumnya dan buku mengenai permainan edukatif, kemampuan visualspasial anak usia 4-6 tahun, dan karakteristik anak usia 4-6 tahun.

2. Tahap kedua (design)

\begin{tabular}{lcr}
\multicolumn{1}{c}{ Tahap } & kedua (design & atau \\
Perancangan) & dilakukan & dengan \\
menyusun & materi modul yang \\
disesuaikan & dengan gambaran
\end{tabular} permasalahan dilapangan pada bulan maret 2020 dan perancangan alat peraga pada bulan April 2020 dengan tujuan menentukan jenis permainan di dalam permainan edukatif berjalan dan berhenti (B\&B), urutan permainan persesinya, serta aturan-aturan dalam permainan edukatif berjalan dan berhenti $(\mathrm{B} \& \mathrm{~B})$ yang dirancang sesuai dengan tujuan yang ingin dicapai dalam permainan edukatif ini.

Pembuatan alat peraga permainan edukatif berjalan dan berhenti (B \& B) memodifikasi APE maze, ragam hias geometri dan puzzle menjadi suatu rangkaian permainan dalam penelitian. Prototype alat peraga dalam permainan ini dibuat menjadi beberapa alas yang terbuat dari bahan flexy 280 yang biasanya digunakan dalam pembuatan spanduk.

Permainan edukatif berjalan dan berhenti (B \& B) terdiri dari 3 sesi. Sesi pertama yaitu ragam bentuk bangun datar B\&B bertujuan agar anak mengetahui 12 macam warna dan mengenal bentuk bangun datar. Sesi kedua yaitu arah jejak kaki berjalan dan berhenti (B \& B) bertujuan agar anak mampu memahami konsep arah dan posisi serta konsep jumlah dan ukuran berjalan dan berhenti yang bertujuan agar anak mampu mengetahui konsep ukuran dan konsep jumlah serta dapat membedakan warna. Sesi ketiga yaitu puzzle rumah berjalan dan berhenti (B \& B) bertujuan agar anak mampu menyusun kepingan puzzle berdasarkan warna dan bentuk bangun datar menjadi gambar utuh berdasarkan contoh gambarnya dan dapat mengalihkan bentuk yang ditangkap mata ke wujud yang lain melalui kegiatan menggambar dan mewarnai bentuk rumah. Peserta dalam permainan ini yaitu anak yang berusia 4- 6 tahun yang berada di kelas TK A dan TK B.

\section{Tahap ketiga (develop)}

Pada tahap ketiga merupakan tahapan yang menunjukkan bahwa modul permainan edukatif berjalan dan berhenti $(B \& B)$ yang telah dirancang peneliti akan divalidasi oleh 4 validator atau ahli pakar atau professional judgement yang telah memiliki pengalaman di bidangnya.

Proses validasi dilakukan memalui proses focuss group discussion (FGD) pada tanggal 27 Oktober 2020, pada jam 13.0014.30 WIB. Validator dalam penelitian ini yaitu Psikolog Pendidikan yang berpengalaman dalam memberikan psikoedukasi kepada anak usia dini, Psikolog Anak yang berpengalaman dalam menangani Anak Usia Dini, Guru TK yang memiliki pengalaman dalam memberikan pendidikan untuk anak usia dini minimal 2 tahun dan Orangtua yang memiliki anak berusia 4-6 tahun.

Validator bertugas dalam menilai modul permainan yang telah dijabarkan dalam form validasi modul. Hasil evaluasi dari validator akan digunakan peneliti untuk merevisi modul yang telah dibuat agar dapat diperoleh modul yang valid dan dapat digunakan untuk mencapai tujuan. 
节

-

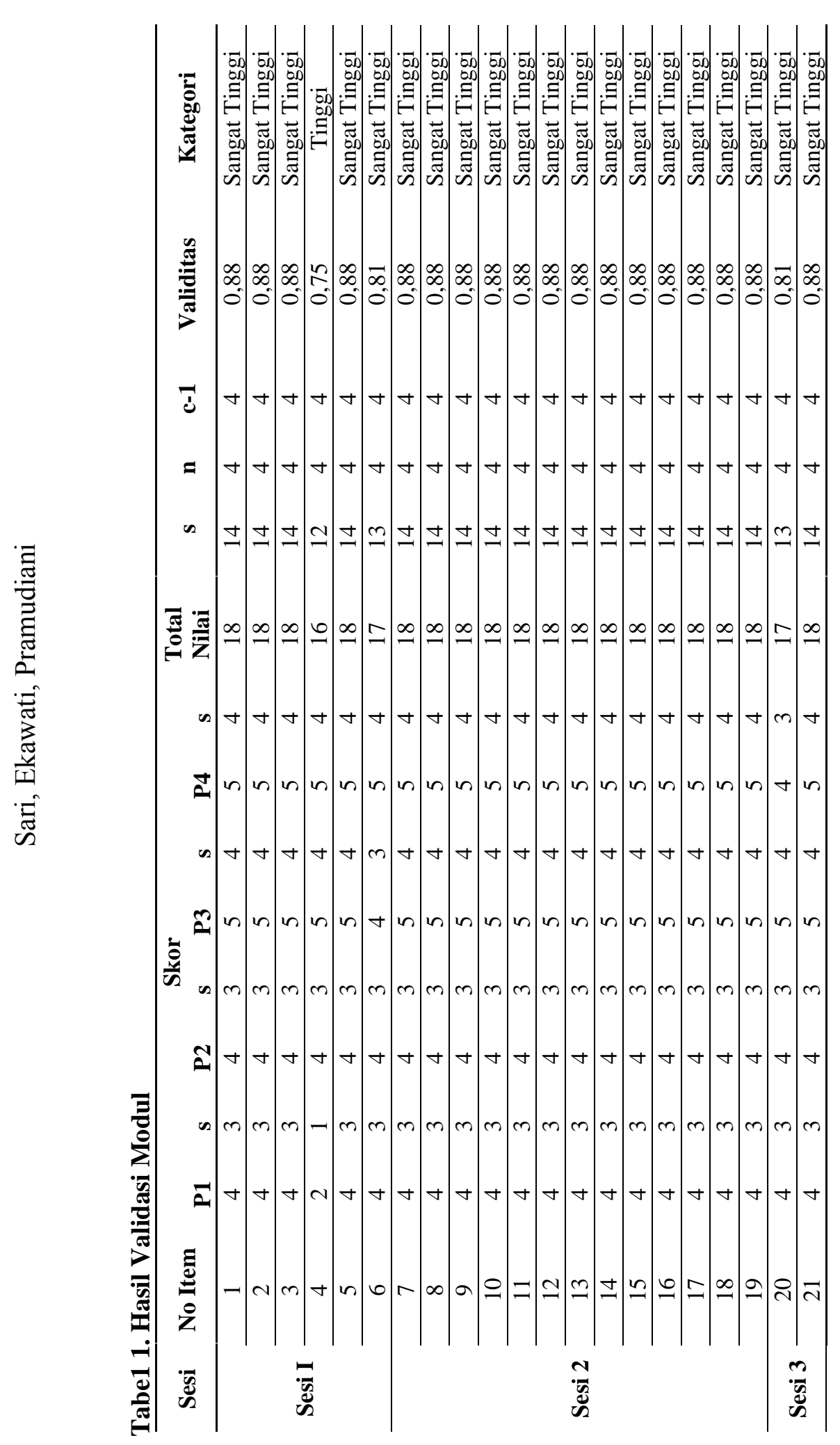

.

कू⿱艹

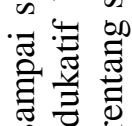

胥司

దू

.

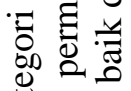

䒕寻

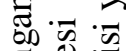

क्ष

$\infty$ 屯.

○”

$\hat{0} \cong \frac{0}{2}$

ซ $\triangleq$

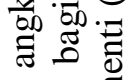

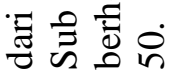

픔 焉

¿ी

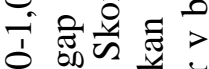

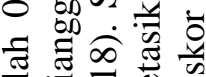

స⿱艹兀)

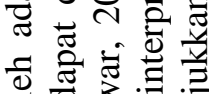

ข

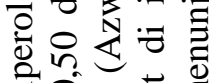

:

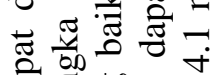

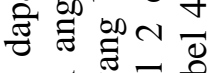

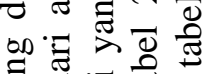

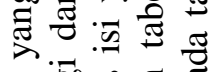

$>$ D.

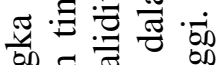

离등

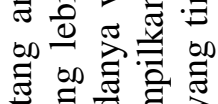

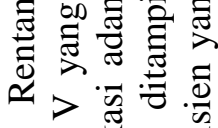

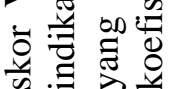


Uji Validitas Isi Modul Permainan Edukatif Berjalan dan Berhenti (B\&B) Untuk Meningkatkan Kemampuan Visual Spasial Anak Usia Dini

Tabel 2. Hasil Validasi Alat Ukur

\begin{tabular}{|c|c|c|c|c|c|c|c|c|c|c|c|c|c|c|c|}
\hline \multirow{2}{*}{ Komponen } & \multirow{2}{*}{$\begin{array}{c}\text { No } \\
\text { Item }\end{array}$} & \multicolumn{8}{|c|}{ Skor } & \multirow{2}{*}{$\begin{array}{l}\text { Total } \\
\text { Nilai }\end{array}$} & \multirow{2}{*}{$\sum \mathrm{s}$} & \multirow{2}{*}{$\mathbf{n}$} & \multirow{2}{*}{$\begin{array}{l}\text { c- } \\
1\end{array}$} & \multirow{2}{*}{ Validitas } & \multirow{2}{*}{ Kategori } \\
\hline & & P1 & $\mathbf{s}$ & $\mathbf{P 2}$ & $\mathbf{s}$ & P3 & $\mathbf{s}$ & $\mathbf{P 4}$ & $\mathbf{s}$ & & & & & & \\
\hline \multirow{9}{*}{$\begin{array}{c}\text { Komponen } \\
1\end{array}$} & 1 & 4 & 3 & 4 & 3 & 5 & 4 & 5 & 4 & 18 & 14 & 4 & 4 & 0,88 & Sangat Tinggi \\
\hline & 2 & 4 & 3 & 4 & 3 & 5 & 4 & 5 & 4 & 18 & 14 & 4 & 4 & 0,88 & Sangat Tinggi \\
\hline & 3 & 4 & 3 & 4 & 3 & 5 & 4 & 5 & 4 & 18 & 14 & 4 & 4 & 0,88 & Sangat Tinggi \\
\hline & 4 & 4 & 3 & 4 & 3 & 5 & 4 & 5 & 4 & 18 & 14 & 4 & 4 & 0,88 & Sangat Tinggi \\
\hline & 5 & 4 & 3 & 4 & 3 & 4 & 3 & 5 & 4 & 17 & 13 & 4 & 4 & 0,81 & Sangat Tinggi \\
\hline & 6 & 4 & 3 & 4 & 3 & 5 & 4 & 5 & 4 & 18 & 14 & 4 & 4 & 0,88 & Sangat Tinggi \\
\hline & 7 & 4 & 3 & 4 & 3 & 5 & 4 & 5 & 4 & 18 & 14 & 4 & 4 & 0,88 & Sangat Tinggi \\
\hline & 8 & 4 & 3 & 4 & 3 & 5 & 4 & 5 & 4 & 18 & 14 & 4 & 4 & 0,88 & Sangat Tinggi \\
\hline & 9 & 4 & 3 & 4 & 3 & 5 & 4 & 5 & 4 & 18 & 14 & 4 & 4 & 0,88 & Sangat Tinggi \\
\hline \multirow{21}{*}{$\begin{array}{c}\text { Komponen } \\
2\end{array}$} & 10 & 4 & 3 & 4 & 3 & 5 & 4 & 5 & 4 & 18 & 14 & 4 & 4 & 0,88 & Sangat Tinggi \\
\hline & 11 & 4 & 3 & 4 & 3 & 5 & 4 & 5 & 4 & 18 & 14 & 4 & 4 & 0,88 & Sangat Tinggi \\
\hline & 12 & 4 & 3 & 4 & 3 & 5 & 4 & 5 & 4 & 18 & 14 & 4 & 4 & 0,88 & Sangat Tinggi \\
\hline & 13 & 4 & 3 & 4 & 3 & 5 & 4 & 5 & 4 & 18 & 14 & 4 & 4 & 0,88 & Sangat Tinggi \\
\hline & 14 & 4 & 3 & 4 & 3 & 5 & 4 & 5 & 4 & 18 & 14 & 4 & 4 & 0,88 & Sangat Tinggi \\
\hline & 15 & 4 & 3 & 4 & 3 & 5 & 4 & 5 & 4 & 18 & 14 & 4 & 4 & 0,88 & Sangat Tinggi \\
\hline & 16 & 4 & 3 & 4 & 3 & 4 & 3 & 5 & 4 & 17 & 13 & 4 & 4 & 0,81 & Sangat Tinggi \\
\hline & 17 & 4 & 3 & 4 & 3 & 4 & 3 & 5 & 4 & 17 & 13 & 4 & 4 & 0,81 & Sangat Tinggi \\
\hline & 18 & 4 & 3 & 4 & 3 & 5 & 4 & 5 & 4 & 18 & 14 & 4 & 4 & 0,88 & Sangat Tinggi \\
\hline & 19 & 4 & 3 & 4 & 3 & 5 & 4 & 5 & 4 & 18 & 14 & 4 & 4 & 0,88 & Sangat Tinggi \\
\hline & 20 & 4 & 3 & 4 & 3 & 5 & 4 & 5 & 4 & 18 & 14 & 4 & 4 & 0,88 & Sangat Tinggi \\
\hline & 21 & 4 & 3 & 4 & 3 & 5 & 4 & 5 & 4 & 18 & 14 & 4 & 4 & 0,88 & Sangat Tinggi \\
\hline & 22 & 4 & 3 & 4 & 3 & 5 & 4 & 5 & 4 & 18 & 14 & 4 & 4 & 0,88 & Sangat Tinggi \\
\hline & 23 & 4 & 3 & 4 & 3 & 5 & 4 & 5 & 4 & 18 & 14 & 4 & 4 & 0,88 & Sangat Tinggi \\
\hline & 24 & 4 & 3 & 4 & 3 & 5 & 4 & 5 & 4 & 18 & 14 & 4 & 4 & 0,88 & Sangat Tinggi \\
\hline & 25 & 4 & 3 & 4 & 3 & 5 & 4 & 5 & 4 & 18 & 14 & 4 & 4 & 0,88 & Sangat Tinggi \\
\hline & 26 & 4 & 3 & 4 & 3 & 5 & 4 & 5 & 4 & 18 & 14 & 4 & 4 & 0,88 & Sangat Tinggi \\
\hline & 27 & 4 & 3 & 4 & 3 & 5 & 4 & 5 & 4 & 18 & 14 & 4 & 4 & 0,88 & Sangat Tinggi \\
\hline & 28 & 4 & 3 & 4 & 3 & 5 & 4 & 5 & 4 & 18 & 14 & 4 & 4 & 0,88 & Sangat Tinggi \\
\hline & 29 & 4 & 3 & 4 & 3 & 5 & 4 & 5 & 4 & 18 & 14 & 4 & 4 & 0,88 & Sangat Tinggi \\
\hline & 30 & 4 & 3 & 4 & 3 & 5 & 4 & 5 & 4 & 18 & 14 & 4 & 4 & 0,88 & Sangat Tinggi \\
\hline \multirow{6}{*}{$\begin{array}{c}\text { Komponen } \\
3\end{array}$} & 31 & 4 & 3 & 4 & 3 & 5 & 4 & 5 & 4 & 18 & 14 & 4 & 4 & 0,88 & Sangat Tinggi \\
\hline & 32 & 4 & 3 & 3 & 2 & 5 & 4 & 4 & 3 & 16 & 12 & 4 & 4 & 0,75 & Tinggi \\
\hline & 33 & 4 & 3 & 4 & 3 & 5 & 4 & 5 & 4 & 18 & 14 & 4 & 4 & 0,88 & Sangat Tinggi \\
\hline & 34 & 4 & 3 & 4 & 3 & 5 & 4 & 5 & 4 & 18 & 14 & 4 & 4 & 0,88 & Sangat Tinggi \\
\hline & 35 & 4 & 3 & 4 & 3 & 4 & 3 & 5 & 4 & 17 & 13 & 4 & 4 & 0,81 & Sangat Tinggi \\
\hline & 36 & 4 & 3 & 4 & 3 & 5 & 4 & 5 & 4 & 18 & 14 & 4 & 4 & 0,88 & Sangat Tinggi \\
\hline
\end{tabular}

Rentang angka $\mathrm{V}$ yang dapat diperoleh adalah $0-1,00$. Setiap skor V yang melebihi dari angka 0,50 dapat dianggap sebagai indikasi adanya validitas isi yang baik (Azwar, 2018). Skor angka yang ditampilkan dalam tabel 2 dapat di interpretasikan sebagai koefisien yang tinggi. Pada tabel 2 menunjukkan skor $\mathrm{v}$ bergerak dari angka 0,75- 0,88 dengan kategori tinggi sampai sangat tinggi. Alat ukur kemampuan visual-spasial anak usia dini memiliki isi yang baik dengan rentang skor diatas 0,50 .

\section{Pembahasan}

Penelitian ini ingin menguji validitas isi modul permainan edukatif berjalan dan berhenti (B \& B) untuk meningkatkan kemampuan visual-spasial anak usia dini. Penelitian ini menggunakan studi deskriptif dengan model 3D (define, design, dan develop).

Permainan edukatif berjalan Dan berhenti (B \& B) ini didesain dengan memperhatikan ciri-ciri kemampuan visual spasial anak usia 4-6 tahun dan memuat 3 komponen kemampuan visual-spasial anak usia dini serta telah dimodifikasi 
pelaksanaannya sesuai dengan kebutuhan assessment. Modul permainan edukatif berjalan dan berhenti (B\&B) yang telah dirancang kemudian divalidasi. Hasil evaluasi dari validator akan digunakan peneliti untuk merevisi modul yang telah dibuat.

Validator menyarankan agar sebelum bermain anak-anak bisa diberikan pengantar terlebih dahulu seperti menggunakan ice breaking (yel-yel, tepuk tangan, menyanyi, gerak anggota badan serta gerak dan lagu) sehingga anak-anak menjadi senang dan bisa mempunyai pengetahuan tentang meteri permainan. Menurut Luthfi (2014) adapun manfaat dari penggunaan ice breaking dalam pembelajaran yaitu; Pertama. Terjadinya proses penyampaian dan penyerapan informasi secara optimal dan maksimal. Kedua, tumbuhnya motivasi guru dan siswa dalam proses pembelajaran. Ketiga, menguatkan hubungan antara guru dengan siswa. Peneliti telah memperbaiki modul permainan dengan menambahkan beberapa ice breaking yang sesuai dengan tujuan yang ingin dicapai dalam setiap sesi permainan.

Validator juga berpendapat untuk mempertimbangkan teknis pelaksanaannya seperti memperhatikan fasilitator yang mendampingi. Menurut Vygotsky (fadilah, 2012) belajar akan terjadi secara efektif dan efisien apabila anak belajar secara kooperatif dengan anak-anak lain dalam suasana dan lingkungan yang mendukung (supportive), dalam bimbingan seseorang yang lebih mampu yaitu orang dewasa atau guru sebagai fasilitator. Peneliti telah memperbaiki kriteria fasiliator dan 2 orang fasilitator yang mendampingi dalam satu kelompok

Pada sesi 1, validator menyarankan agar desain permainan dibuat menjadi 2 spanduk agar anak-anak tidak ragu atau binggung dan lebih leluasa dalam memainkannya. Menurut Kustiawan (2016) salah satu asas komposisi dalam pembuatan media sederhana yaitu kesederhanaan (simplicity). Dalam asas kesederhanaan dalam pembuatan media umumnya dibuat sederhana sehingga mudah dipahami dan tidak membinggungkan anak. Dalam penyajiannya bisa dengan cara menyederhanakannya, menghilangkan bagian-bagian yang tidak penting, dan membagi ke dalam beberapa bagian. Peneliti telah memperbaiki desain permainan dengan membaginya menjadi 2 spanduk yang setiap spanduknya terdiri atas 3 bangun datar.

Pada sesi 2, Validator mengatakan bahwa permainan pada sesi 2 yaitu arah jejak Kaki B\&B jarak antara setiap bentuk bangun datar dalam permainannya harus diperbaiki agar tidak terlalu berdekatan, sehingga anak tidak ragu ketika memilih dan berdiri di atas bentuk bangun datarnya. Menurut Kustiawan (2016) salah satu komposisi dalam pembuatan media sederhana yaitu keseimbangan (balance). Dalam menyusun media sederhana adanya keseimbangan melalui penyusunan unsurunsur visual secara seimbang antara lain samping-menyamping/ kanan- kiri, atasbawah, sudut- menyudut dan depanbelakang. Peneliti telah memperbaiki jarak antara setiap bentuk bangun datar dalam desain permainan ini.

Pada sesi 3 "Puzzle rumah B\&B dan media puzzle pada alat ukur kemampuan visual spasial, Validator menyarankan agar mempertimbangkan kembali ukuran serta jumlah kepingan puzzle yang digunakan agar bisa lebih disederhanakan. Menurut Rahayu (2014) golongan tingkat kesulitan puzzle terdiri atas 3 golongan yaitu: 1 . Golongan tingkat mudah terdiri atas 4-5 keping puzzle, 2. Golongan tingkat sedang terdiri atas 6-10 keping puzzle dan Golongan tingkat sulit terdiri atas 15-30 keping puzzle. Berdasarkan STTPA Alazhar (2019) TK A menyusun puzzle 6-10 keping serta TK B menyusun puzzle lebih dari 8 keping. Sehingga peneliti telah memperbaiki jumlah keping puzzle yang digunakan dalam permainan sesi ke-3 dan alat ukur dari 20 keping puzzle menjadi 9 keping puzzle. 
Validator juga menyarankan agar memperbaiki tata letak dari puzzle. Untuk kepingan yang susunannya agak rumit agar diletakkan di akhir sehingga anak bisa menyusun kepingan puzzle dari yang mudah dulu hingga sulit. Sejalan dengan teori Susanto (Pratiwi, 2017) mengemukakan bermain dapat membentuk sikap mental dan nilai-nilai kepribadian pada anak. Anak bisa belajar menyelesaikan masalah dalam kesulitan terendah sampai tertinggi dan dengan bermain itu anak belajar menyadari keteraturan, peraturan dan berlatih menjalankan komitmen yang dibangun dalam permain tersebut. Peneliti telah memperbaiki tata letak dari desain permainan puzzle rumah $(\mathrm{B} \& \mathrm{~B})$.

Berdasarkan hasil validasi isi modul rentang angka skor $\mathrm{V}$ yang dapat diperoleh adalah $0-1,00$. Setiap skor V yang melebihi dari angka 0,50 dapat dianggap sebagai adanya validitas isi yang baik (Azwar, 2018). Jadi skor angka dapat di interpretasikan sebagai koefisien yang tinggi. Skor V bergerak dari angka 0,750,88 dengan kategori tinggi sampai sangat tinggi. Sub bagian pada masing-masing sesi dari permainan edukatif berjalan dan berhenti (B\&B) memiliki isi yang baik dengan rentang skor di atas 0,50 .

Hasil validasi alat ukur rentang angka $\mathrm{V}$ yang dapat diperoleh adalah 01,00. Setiap skor V yang melebihi dari angka 0,50 dapat dianggap sebagai adanya validitas isi yang baik (Azwar, 2018:179). Jadi, Skor angka dapat di interpretasikan sebagai koefisien yang tinggi. Skor V bergerak dari angka 0,75-0,88 dengan kategori tinggi sampai sangat tinggi. Alat ukur kemampuan visual-spasial anak usia dini memiliki isi yang baik dengan rentang skor diatas 0,50 .

Penelitian ini menerapkan permainan edukatif Berjalan dan Berhenti (B\&B) kepada anak usia dini yang dapat membantu dalam meningkatkan perkembangan anak serta melatih atau menstimulasi kemampuan visual-spasial pada anak. Sesuai dengan penelitian
Syamsuardi (2012) dimana hasil penelitiannya menunjukkan pelaksanaan pembelajaran di taman kanak-kanak tidak lepas dari penggunaan alat permainan sebagai alat pendukung kelancaran dan keberhasilan proses pembelajaran. Penggunaan alat permainan edukatif didasarkan kepada usia serta aspek perkembangan yang ingin dicapai. Dengan menggunakan alat peraga atau permainan anak dapat lebih cepat menangkap materi atau tema pembelajaran yang diberikan dan tidak memberikan beban belajar kepada anak.

Hasil penelitian ini sejalan dengan penelitian yang dilakukan oleh Pradnyawati, dkk (2017) dimana hasil penelitian menunjukkan adanya pengaruh yang signifikan pembelajaran ragam hias geometri terhadap kecerdasan visual spasial pada kelompok eksperimen. Pada sesi pertama yaitu ragam bentuk bangun datar berjalan dan berhenti didesain dengan 6 bentuk bangun datar agar anak bisa mengenal bentuk bangun datar serta setiap bangun datar, tanda silang serta jejak kaki dan telapak tangan diberikan warna yang berbeda agar anak bisa mengetahui macammacam warna (12 warna).

Permainan konsep jumlah dan ukuran didesain dengan beberapa bentuk bangun datar yang berbeda ukuran, warna serta jumlahnya agar anak bisa membedakan warna seperti merah muda-merah tua, hijau muda-hijau tua serta biru muda-biru tua, mengetahui konsep jumlah seperti banyaksedikit, dan mengetahui konsep ukuran seperti tinggi-rendah, besar-kecil, dan panjan-pendek.

Sesuai dengan penelitian Rosidah (2014) dimana penelitian tersebut membuktikan adanya peningkatan kecerdasan visual anak TK Utsmanil Hakim, Tanah Sareal-Bogor melalui permainan maze dengan berbagai modifikasi sebanyak 40,62\%. Sehingga dapat disimpulkan Permainan maze bisa meningkatkan kecerdasan visual-spasial pada anak TK pada kelompok B. Pada sesi kedua yaitu arah jejak kaki B \& B, 
memodifikasi permainan maze agar anak bisa diperkenalkan konsep arah yaitu kanan-kiri, lurus-belok, maju-mundur serta konsep posisi seperti atas-bawah, di dalamdi luar, di depan-di belakang, kanan-kiri.

Hasil penelitian ini juga sejalan dengan penelitian Anjani dan Nurjanah (2014) dimana hasil penelitian menunjukkan adanya pengaruh permainan puzzle terhadap perkembangan kecerdasan visual-spatial anak usia 4-5 tahun di TK AlFath Desa Keboan Anom Gedangan Sidoarjo sehingga, permainan puzzle bisa digunakan untuk media pembelajaran dalam mengasah kecerdasan visual-spatial pada anak. Permainan ini memodifikasi bentuk puzzle. Puzzle rumah ini terdiri atas susunan bentuk bangun datar yang berwarna agar anak bisa menyusun puzzle berdasarkan warna, bentuk, posisi dan ukuran.

$$
\text { Sesuai dengan ciri-ciri }
$$

perkembangan kecerdasan visual-spasial anak berusia 4-6 tahun menurut surya (Anjani dan Nurjanah, 2014) bahwa anak bisa mengetahui 12 warna, anak bisa bermain puzzle tiga dimensi atau puzzle dua dimensi hingga 20 keping, anak sudah bisa dikenalkan dengan bentuk segi yang lebih rumit misalnya segi tujuh (heptagon) sampai segi sepuluh, anak sudah memahami semua konsep arah dan posisi seperti kanan-kiri, atas-bawah, depanbelakang, maju-mundur, dan lurus-belok serta anak sudah memahami konsep jumlah (banyak-sedikit) serta konsep ukuran (besar-kecil, panjang-pendek).

Berdasarkan hasil uji validitas isi modul permainan edukatif berjalan dan berhenti (B \& B) untuk meningkatkan kemampuan visual spasial anak usia dini yang telah dinilai oleh validator telah memiliki isi yang baik, meskipun dengan beberapa saran perbaikan berupa teknis pelaksanaan dan desain permainan. Saran perbaikan yang telah diberikan oleh validator telah peneliti tindaklanjuti dengan merevisi modul permainan edukatif berjalan dan berhenti (B \& B) sehingga didapatkan produk akhir berupa modul permainan edukatif berjalan dan berhenti (B\&B) untuk meningkatkan kemampuan visual spasial yang telah relevan dan sesuai antara isi materi modul dengan tujuan yang ingin dicapai dalam modul permainan ini.

\section{Kesimpulan dan Saran}

Berdasarkan penelitian yang dilakukan pada uji validitas isi modul permainan edukatif berjalan dan berhenti (B \& B) untuk meningkatkan kemampuan visual-spasial anak usia dini, maka dapat ditarik kesimpulan sebagai berikut:

1. Adanya kesesuaian hasil skor uji validitas isi modul permainan edukatif berjalan dan berhenti (B \& B) terhadap kemampuan visual-spasial anak usia dini berdasarkan hasil uji validitas isi modul.

2. Hasil validasi modul yang telah dinilai oleh para validator pada sub bagian modul persesi dari permainan edukatif berjalan dan berhenti (B \& B) memiliki isi yang baik dengan rentang skor sesi 1 bergerak dari 0,75- 0,88, sesi 2 dengan skor 0,88 serta sesi 3 bergerak dari 0,81-0,88.

3. Hasil validasi isi modul permainan eduaktif berjalan dan berhenti (B\&B) yang dinilai oleh validator menunjukkan rentang skor $\mathrm{V}$ bergerak dari 0,75-0,88 dengan kategori tinggi sampai sangat tinggi. Sub bagian pada masing-masing sesi dari permainan edukatif berjalan dan berhenti $(\mathrm{B} \& \mathrm{~B})$ memiliki isi yang baik dengan rentang skor diatas $0,50$.

4. Hasil validasi alat ukur yang telah dinilai oleh validator menunjukkan rentang angka skor $\mathrm{V}$ bergerak dari angka $0,75-0,88$ dengan kategori tinggi sampai sangat tinggi. Alat ukur kemampuan visual-spasial anak usia dini pada setiap sesi menunjukkan skor $\mathrm{V}$ diatas 0,50 sehingga memiliki isi yang baik. Sub bagian aitem kemampuan visual-spasial untuk komponen 1 bergerak dari angka skor V 0,81-0,88, komponen 2 dengan rentang angka skor $\mathrm{V}$ 0,81-0,88 dan 
Uji Validitas Isi Modul Permainan Edukatif Berjalan dan Berhenti (B\&B) Untuk Meningkatkan Kemampuan Visual Spasial Anak Usia Dini

komponen 3 dengan rentang angka skor V 0,75-0,88.

Berdasarkan hasil penelitian yang telah dicapai, serta mengingat masih banyaknya keterbatasan dalam penelitian ini, maka peneliti memberikan beberapa saran agar sekolah dan dunia pendidikan pada umumnya menjadikan penelitian ini sebagai bahan pertimbangan untuk mengembangkan media pembelajaran dalam menyusun program pendidikan bagi anak usia dini. Sedangkan bagi peneliti selanjutnya untuk dapat mengembangkan permainan edukatif berjalan dan berhenti (B \& B) dan skala kemampuan visual spasial serta mengembangkan media permainan lain untuk meningkatkan kemampuan visual spasial. Penelitian ini terbatas hanya pada kecerdasan visual spasial, diharapkan peneliti selanjutnya mampu mengembangkan skala atau permainan untuk melihat dan meningkatkan kecerdasan majemuk lainnya.

\section{Daftar Pustaka}

Anjani, D. A., \& Nurjanah, S. (2014). Permainan Puzzle Mempengaruhi Perkembangan Kecerdasan VisualSpatial Anak Usia 4-5 Tahun Di Tk Al-Fath Desa Keboan Anom Gedangan Sidoarjo. Journal of Health Sciences, 7(2).

Azwar, S. (2018). Metode Penelitian Psikologi Edisi II. Yogyakarta: Pustaka Pelajar.

Desmita. (2015).. Bandung: PT Remaja Rosdakarya Perkembangan.

Elfiadi, E. (2017). Kecerdasan Jamak Pada Anak Usia Dini. Itqan: Jurnal Ilmu Kependidikan, 8(2), 35-52.

Fadilah. (2012). Teori belajar Konstruktivistik Vygotsky. Jurnal Psikologi Belajar Vol 1
Kemendikbud. (2019). Mendikbud: Pentingnya Konsep Bermain dan Belajar di Jenjang PAUD diakses dari https://www.kemdikbud.go.id.

Kustiawan,Usep. (2016). Pengembangan Media Pembelajaran Anak Usia Dini. Malang: Gunung Samudera.

Luthfi, M. F. (2014). Pembelajaran Menggairahkan Dengan Ice Breaking. Madinah: Jurnal Studi Islam, 1(1), 27-29.

Marlisa, L. (2016). Tuntutan Calistung Pada Anak Usia Dini. Jurnal ilmiah tumbuh kembang anak usia dini. Volume 1 no 3.

Pradnyawati, N. L. G. N., Antara, P. A., Ujianti, P. R., \& Psi, S. (2017). Pengaruh Ragam Hias Geometri Terhadap Kecerdasan Visual Spasial Pada Anak Gugus V Kecamatan Kediri Kabupaten Tabanan. Jurnal Pendidikan Anak Usia Dini Undiksha, 5(1).

Pratiwi, W. (2017). Konsep bermain pada anak usia dini. TADBIR: Jurnal Manajemen Pendidikan Islam, 5(2), 106-117.

Rahayu, Fuji.Y. (2014). Peningkatan Kemampuan Kognitif Anak Melalui Bermain Puzzle Di Kelompok B Tk Dharma Wanita Sidowarek II Plemahan-Kediri. Paud Teratai, 3(1).

Republik Indonesia, (2003). UndangUndang Republik Indonesia Nomor 20 Tahun2003 Tentang Sistem Pendidikan Nasional. Retrieved from http://kelembagaan.ristekdikti.go.id/ wpcontent/uploads/2016/08/UU no $\underline{0 \text { th2003.pdf }}$

Rosidah, L. (2014). Peningkatan Kecerdasan Visual Spasial Anak Usia Dini Melalui Permainan 
Sari, Ekawati, Pramudiani

Mazelaily Rosidah. Jurnal

Kanak-Kanak Paud Polewali

Pendidikan Usia Dini, 8(2), 291Kecamatan Tanete Riattang Barat 300.

Kabupaten Bone.Publikasi

Pendidikan, 2(1).

Susanto, A. (2017). Pendidikan Anak Usia Dini (Konsep dan Teori). Jakarta: Bumi Aksara.

Syamsuardi, S. (2012). Penggunaan Alat Permainan Edukatif (Ape) Di Taman

Uno, Hamzah.B \& Kuadrat, Masri. (2014). Mengelola Kecerdasan Dalam Pembelajaran: Sebuah Konsep Pembelajaran Berbasis Kecerdasan. Jakarta: Bumi Aksara. 